\title{
Integrated Management of Root-Knot Nematode, Meloidogyne javanica Infected Cucumber and Courgette
}

\author{
M.S. Abo-Korah
}

Econ. Ent. \& Agric. Zoology Dept., Fac. Agric., Menoufia Univ., Shebin Elkom, Egypt.

\begin{abstract}
This work was conducted to study the effect of nematode - trapping fungus (Arthrobotrys conoides); white wormwood (Artemisia herba alba) and the nematicides, Tervigo (half dose) in the integrated control programs of plant parasitic nematodes. These agents were evaluated alone as well as in combination against Meloidogyne javanica infected Cucumber and Courgette under greenhouse conditions, at the Experimental Farm, Faculty of Agriculture, Menoufia University, Shibin El-Kom, Egypt. The obtained results showed that, the application of $A$. conoides + Wormwood + Tervigo treatment gave the highest reduction percentage of the nematode with reduction ratio of $(85.0 \%)$ followed by the treatment of $A$. conoides + Tervigo $(77.3 \%)$ in Cucumber plants and the same previous treatments gave $(80.0 \%$ and $70.5 \%)$ in Courgette plants, respectively. Moreover, the two previous applications gave better enhancement in various growth parameters such as, plant height, shoot weight, and root weight in both Cucumber and Courgette plants. The same application gave the lowest gall index (1.0) representing the highest total decrease in gall numbers $(-83.3 \%)$ in cucumber and $(-81.8 \%)$ in Courgette compared with control. There are significant differences in root gall index between control treatment and all other treatments. Results indicate that Tervigo as a nematicide had no adverse effects on the predaceous activity of $A$. conoides. Moreover, dried leaves of Wormwood play an important role in nematode control, as well as it promoting plant growth and enhancing beneficial microorganisms in soil.
\end{abstract}

Keywords: IPM, Meloidogyne, Wormwood, Arthrobotrys conoides, biological control.

\section{Introduction}

The need for integrated pest management is so great nowadays. Actually, it began developing many years ago, when combination of biological, cultural, chemical control were used to monitor nematodes on a single crop (Akhtar and Alam, 1991, and Mostafa, 2001).

Cucumber (Cucumis sativus) and Courgette (Cucurbita pepo) have occupied an important position among other truck crops. Rests attack these plants led to high losses in crop yield.

Root-knot nematodes are recognized as major agricultural pathogens which attack plants causing crop losses allover the world. These nematodes produce an 
annual loss of over US \$ 100 billion to world agriculture and an estimated US \$500 million are usually spent on nematode control (Keren-Zur et al., 2000).

Root-knot nematodes are the most damaging plant-parasitic nematode (Barker, 1985). It caused root galls to develop as these microscopic parasites feed in the roots of the plants.

Arthrobotrys conoides is trapping fungi which immobilize nematodes using non-adhesive knobs and constricting rings. They ensnare active nematodes using one or more types of mycelial traps. Some Arthrobotrys species have been formulated and applied, but they have given mixed results (Viaene et al., 2006). Antagonistic fungi are continuously attracting great attention as potential alternatives to chemical control of root-knot nematodes (Seyedeh et al., 2015). They are natural enemies of nematodes and are considered as ideal agents for controlling parasitic nematodes of plants and animals (Moosavi and Zare, 2012).

Wormwood is an organic amendment, herbaceous plant grown at the Western desert in Egypt and this is a first trial to employed it as a treatment against $M$. javanica in the present investigation alone and in different combination with the rest treatments under study.

The present study was carried out to determine the impact of Arthrobotrys conoides, combined with wormwood as organic amendment as well as Tervigo nematicide (half dose) in management of $M$. javanica infected Cucumber and Courgette under greenhouse conditions.

\section{Materials and Methods}

\section{Nematode culture:}

Juveniles of the root knot nematode, Meloidogyne javanica were obtained from the pure culture reared on black nightshade, Solanum nigrum plants in the Nematode Laboratory of the Entomology and Zoology Department of Faculty of Agriculture, Menoufia University.

\section{Materials preparation:}

\section{Arthrobotrys conoides preparation:}

The isolated fungus was obtained from Agricultural Botany Department of Faculty of Agriculture, Menoufia University. The obtained nematophagous fungus was maintained in Petri dishes contained CMA (15 g/l) media by using $5 \mathrm{~mm}$ fungal disc from 7-day-old cultures and incubated at $25 \pm 2{ }^{\circ} \mathrm{C}$ for $7-10$ days. The obtained nematophagous fungus was purified and single spore isolation was made for the fungus on CMA medium. Spore suspension was adjusted to a concentration of $1 \times 10^{8}$ spores $/ \mathrm{ml}$ distilled water. A. conoides was identified and classified according to (Cooke and Godfrey, 1964) and (Van Oorschot, 1985). 


\section{Artemisia herba-alba preparation:}

White Wormwood, A. herba-alba is a herbal plant have strong aromas and bitter tastes from terpenoids and sesquiterpene lactones, which exists as an adaptation to discourage herbivory, which was applied as dry powder of leaves and stems at the rate of $3 \mathrm{~g} / \mathrm{plant}$.

\section{Tervigo:}

Tervigo $^{T M}$ is a suspension concentrate (SC) containing $20 \mathrm{~g} / \mathrm{L}$ abamectin with the addition of an iron chelate Fe-EDDHA 400g/L produced by Syngenta East Africa Ltd. Abamectin as an active ingredient provides effective control of nematodes, while the iron chelate is a micro fertilizer that provides crop enhancement effects especially in alkaline soils. After one week of seedlings adaptation, Tervigo was applied as $0.2 \mathrm{ml}$ per pot as soil drench around the roots (half recommended dose).

\section{Experimental preparation and design:}

The effect of treatments on Cucumber, Cucumis sativus (Variety hybrid Kardosa) and Courgette, Cucurbita pepo (Variety hybrid CA2707) was carried out under greenhouse conditions at the Experimental Farm, Faculty of Agriculture, Menoufia University, Shebin Elkom, Egypt. Twenty seven plastic pots $25 \mathrm{~cm}$ in diameter filled with $4 \mathrm{~kg}$ sterilized clay-sand mixed soil $(1: 1, \mathrm{v} / \mathrm{v})$ were prepared and three seedlings ( 5 weeks old) of Cucumber were planted in it, other group of pots were prepared as previous mentioned and planted with Courgette seedlings.

The tested agents were applied one week after planting seedlings then , three days later, $1000 \mathrm{~J} 2$ of $M$. javanica were added by pipette into three holes around the seedlings.

A randomized complete block design with three replicates was used. Pots were irrigated as needed and fertilized every four weeks. The experiment was terminated 90 days after planting.

At the end of the experiment, roots and shoots fresh weight, plant height were determined and recorded.

\section{Nematode Extraction and Enumeration:}

Each composite soil sample was carefully mixed, and an aliquot of $100 \mathrm{~cm}^{3}$ was processed for nematode extraction according to methods described by Southey (1970), each treatment was replicated three times. About $300-400 \mathrm{ml}$ of water were added to the soil in a glass beaker $(1000 \mathrm{ml})$ and the mixture was agitated by fingers, after few seconds the suspension was poured onto a 60 meshsieve and passing suspension was collected in another clean glass beaker. Materials caught on the 60 mesh-sieve were discarded, while the collected suspension was then poured onto a 200 mesh-sieve. Materials remain on the sieve 
were thoroughly washed by a gentle streamed of water into a $200 \mathrm{ml}$ beaker. The resulting suspension containing nematodes was then transferred to a Modified Baermann pan fitted with soft tissue paper for the separation of active nematodes from debris and fine soil particles. After $72 \mathrm{hr}$, nematode water suspension was collected and concentrated to $20 \mathrm{ml}$ in a vial by using a 350 mesh-sieve. An aliquant of $1 \mathrm{ml}$ each of nematode suspensions were pipetted off, placed in a Hawksley counting slide and examined by using a stereomicroscope. Nematode counts were done after 1,2, and 3 months of application.

Roots were carefully washed, and the nematode galls were counted and rated as mentioned in Table (1), as well as one gram per root was stained by acid fuchsin lactophenol to count root knot nematode stages inside the roots with the aid of dissecting microscope.

\section{Statistical analysis:}

The obtained data were subjected to analysis of variance (ANOVA) using CoStat Software, Version 6.4 (2008). The mean differences were compared to Duncan's Multiple Range Test (DMRT).

Reduction percentages was computed according to Abbott formula (1925). Increase or decrease \%: Control - treatment / Control $\times 100$.

Table (1): Rating scale for the assessment of level of resistance or susceptible number of galls.

\begin{tabular}{ccc}
\hline Number of galls & Galling index & Resistance rating \\
\hline 0 & 0 & Immune \\
$1-2$ & 1 & Highly resistant \\
$3-10$ & 2 & Resistant \\
$11-30$ & 3 & Moderately resistant \\
$31-70$ & 4 & Moderately susceptible \\
$71-100$ & 5 & Susceptible \\
$>100$ & 6 & Highly susceptible \\
\hline
\end{tabular}

\section{Results and Discussion}

\section{Cucumber experiments:}

The statistical analysis of the obtained data Table (2) indicate that all treatments significantly suppressed nematode population in the soil $30,60,90$ days after treatment in comparison with control. 
The highest reduction percentages of the nematode in the soil was recorded with the treatments of $A$. conoides + Wormwood + Tervigo and $A$. conoides + Tervigo with 85.0 and $77.3 \%$, respectively, while the least results was recorded with Wormwood alone (55.7\%) and A. conoides alone (60.6\%).

These results supporting by the findings of Mostafa (2001) who reported that the integrated of caster $+A$. oligospors + oxamyl were effective in reducing the nematode population and increase plant growth and yield than when used alone.

Regarding to the influence of treatments on some cucumber plant characters and root gall index, the statistical analysis of the obtained data in Table (3) indicated that there are significant differences in all tested measurements between control and all other treatments.

Table (2): Effect of treatments on the population density of root-knot nematode, $M$. javanica infected Cucumber plants and reduction \% ,under shield conditions.

\begin{tabular}{|c|c|c|c|c|c|c|c|c|}
\hline \multirow{2}{*}{ Treatments } & \multicolumn{4}{|c|}{$\begin{array}{c}\text { Aver. no. of Meloidogyne } \\
\text { javanica juveniles/ } 100 \mathrm{~g} \text { soil } \\
\text { Days post-treatments }\end{array}$} & \multicolumn{4}{|c|}{ Reduction \% } \\
\hline & $\begin{array}{c}30 \\
\text { Days }\end{array}$ & $\begin{array}{c}60 \\
\text { Days } \\
\end{array}$ & $\begin{array}{c}90 \\
\text { Days } \\
\end{array}$ & $\begin{array}{l}\text { Overall } \\
\text { mean }\end{array}$ & $\begin{array}{c}30 \\
\text { Days } \\
\end{array}$ & $\begin{array}{c}60 \\
\text { Days } \\
\end{array}$ & $\begin{array}{c}90 \\
\text { Days } \\
\end{array}$ & $\begin{array}{c}\text { overall } \\
\text { mean }\end{array}$ \\
\hline A. conoides & $\begin{array}{c}750.0 \\
c\end{array}$ & $\begin{array}{c}502.3 \\
c\end{array}$ & $\begin{array}{c}365.9 \\
c\end{array}$ & $\begin{array}{l}539.4 \\
c\end{array}$ & 24.4 & 64.4 & 78.5 & 60.6 \\
\hline Wormwood & $\begin{array}{c}823.1 \\
b\end{array}$ & $\begin{array}{c}582.3 \\
b\end{array}$ & $\begin{array}{c}411.6 \\
b\end{array}$ & $\begin{array}{c}605.7 \\
b\end{array}$ & 17.0 & 58.7 & 75.8 & 55.7 \\
\hline Tervigo & $\begin{array}{c}547.8 \\
\mathrm{e}\end{array}$ & $\begin{array}{c}301.2 \\
\mathrm{e}\end{array}$ & $\begin{array}{c}285.0 \\
d\end{array}$ & $\begin{array}{c}378.0 \\
e\end{array}$ & 44.8 & 78.6 & 83.2 & 72.4 \\
\hline $\begin{array}{l}\text { A. conoides + } \\
\text { Wormwood }\end{array}$ & $\begin{array}{l}702.0 \\
d\end{array}$ & $\begin{array}{c}496.5 \\
\quad c\end{array}$ & $\begin{array}{c}371.6 \\
\quad c\end{array}$ & $\begin{array}{c}523.4 \\
d\end{array}$ & 29.2 & 64.8 & 78.1 & 61.7 \\
\hline A. conoides + Tervigo & $\begin{array}{c}474.5 \\
g\end{array}$ & $\begin{array}{c}257.6 \\
f\end{array}$ & $\begin{array}{l}197.5 \\
\quad f\end{array}$ & $\begin{array}{l}309.9 \\
f\end{array}$ & 52.1 & 81.8 & 88.4 & 77.3 \\
\hline Wormwood + Tervigo & $\begin{array}{c}530.0 \\
f\end{array}$ & $\begin{array}{l}400.0 \\
d\end{array}$ & $\begin{array}{c}210.5 \\
\mathrm{e}\end{array}$ & $\begin{array}{c}380.0 \\
\mathrm{e}\end{array}$ & 46.6 & 71.6 & 87.6 & 72.2 \\
\hline $\begin{array}{l}\text { A. conoides }+ \\
\text { Wormwood + Tervigo }\end{array}$ & $\begin{array}{c}370.5 \\
\mathrm{~h}\end{array}$ & $\begin{array}{c}189.5 \\
g\end{array}$ & $\begin{array}{c}57.0 \\
g\end{array}$ & $\begin{array}{c}205.7 \\
g\end{array}$ & 62.6 & 86.6 & 96.7 & 85.0 \\
\hline $\begin{array}{l}\text { Control } \\
\text { (nematode only) }\end{array}$ & $\begin{array}{l}991.5 \\
a\end{array}$ & $\begin{array}{c}1410.1 \\
a\end{array}$ & $\begin{array}{c}1700.0 \\
a\end{array}$ & $\begin{array}{c}1367.2 \\
a\end{array}$ & - & - & - & - \\
\hline Check & 0 & 0 & 0 & 0 & 0 & 0 & 0 & 0 \\
\hline LSD 5\% & 9.3 & 8.7 & 8.7 & 8.7 & - & - & - & - \\
\hline
\end{tabular}


Table (3): Influence of treatments on some Cucumber plant characters and root gall index.

\begin{tabular}{lcccc}
\hline \multicolumn{1}{c}{ Treatments } & $\begin{array}{c}\text { plant } \\
\text { height cm }\end{array}$ & $\begin{array}{c}\text { shoot } \\
\text { weight }\end{array}$ & $\begin{array}{c}\text { root } \\
\text { weight g }\end{array}$ & $\begin{array}{c}\text { root gall } \\
\text { index }\end{array}$ \\
\hline A. conoides & 79.0 & 61.4 & 6.9 & 3.5 \\
& $\mathrm{f}$ & $\mathrm{d}$ & $\mathrm{d}$ & $\mathrm{bc}$ \\
Wormwood & 95.4 & 69.3 & 7.0 & 4.0 \\
Tervigo & $\mathrm{d}$ & $\mathrm{C}$ & $\mathrm{d}$ & $\mathrm{b}$ \\
& 77.9 & 55.0 & 7.9 & 3.0 \\
A. conoides + Wormwood & $\mathrm{f}$ & $\mathrm{e}$ & $\mathrm{cd}$ & $\mathrm{bc}$ \\
& 99.0 & 71.9 & 9.0 & 3.0 \\
A. conoides + Tervigo & $\mathrm{c}$ & $\mathrm{C}$ & $\mathrm{c}$ & $\mathrm{bc}$ \\
& 80.4 & 62.8 & 8.1 & 2.5 \\
Wormwood + Tervigo & $\mathrm{f}$ & $\mathrm{d}$ & $\mathrm{cd}$ & $\mathrm{bc}$ \\
& 88.5 & 61.4 & 8.4 & 2.0 \\
A. conoides + Wormwood + Tervigo & 115.8 & 81.3 & $\mathrm{~cd}$ & $\mathrm{~cd}$ \\
& $\mathrm{~b}$ & $\mathrm{~b}$ & $\mathrm{~b}$ & 1.0 \\
Control (nematode only) & 33.5 & 18.9 & 3.2 & $\mathrm{~d}$ \\
& $\mathrm{~g}$ & $\mathrm{f}$ & $\mathrm{e}$ & $\mathrm{a}$ \\
Check & 119.6 & 88.8 & 12.7 & $\mathrm{a}$ \\
LSD 5\% & $\mathrm{a}$ & $\mathrm{a}$ & $\mathrm{a}$ & 0 \\
\hline
\end{tabular}

Means in each column followed by the same letter (s) are not significantly different at $5 \%$ level.

It was clearly show that all treatments led to considerable increase in plant height, shoot weight and root weight and considerable decrease on root gall index (RGI) comparing with control .

The highest increase in vegetative characters were obtained at the treatment of (A.conoides + Wormwood + Tervigo) while the least increase was observed at Tervigo (half dose) treatment.

As for the increase or decrease percentages of the tested characters, the obtained results in Table (4) indicated that all plant treatments increased plant height, shoot weight, root weight, while it decreased root gall index.

Table (4): Increase or decrease percentages of some vegetative characters and gall index on Cucumber as influenced by treatment applications.

\begin{tabular}{lcccc}
\hline \multicolumn{1}{c}{ Treatments } & $\begin{array}{c}\text { plant } \\
\text { height } \\
\text { \% }\end{array}$ & $\begin{array}{c}\text { shoot } \\
\text { weight } \\
\%\end{array}$ & $\begin{array}{c}\text { root } \\
\text { weight } \\
\%\end{array}$ & $\begin{array}{c}\text { root gall } \\
\text { index } \\
\%\end{array}$ \\
\hline A. conoides & 135.8 & 244.8 & 115.6 & -41.7 \\
Wormwood & 187.6 & 266.7 & 118.7 & -33.3 \\
Tervigo & 132.5 & 191.0 & 146.8 & -50.0 \\
A. conoides + Wormwood & 195.5 & 280.4 & 181.3 & -50.0 \\
A. conoides + Tervigo & 140.0 & 232.3 & 153.1 & -58.3 \\
Wormwood + Tervigo & 164.2 & 224.8 & 162.5 & -66.7 \\
A. conoides + Wormwood + Tervigo & 245.6 & 330.1 & 237.5 & -83.3 \\
Control (nematode only) & - & - & - & - \\
Check & 257.0 & 369.8 & 296.9 & - \\
\hline
\end{tabular}




\section{Courgette experiments:}

Data presented in Table (5) show the side effect of treatments on the population density of root-knot nematode, Meloidogyne javanica infected Courgette plants and reduction $\%$,under shield conditions. The statistical analysis of the obtained data indicate that all tested treatments significantly suppressed nematode population in the soil $30,60,90$ days after treatment in comparison with control.

The highest reduction percentages of the nematode in the soil, was recorded at the treatment of ( $A$. conoides + Wormwood + Tervigo), followed by ( $A$. conoides + Tervigo) with reduction of $(80.0$ and $70.5 \%)$ respectively, while the least reduction $\%$ was recorded with $A$. conoides alone $(51.8 \%)$ and wormwood alone (45.3\%).

Table (5): Effect of treatments on the population density of root-knot nematode, Meloidogyne javanica infected Courgette plants and reduction \% ,under shield conditions.

\begin{tabular}{|c|c|c|c|c|c|c|c|c|}
\hline \multirow[t]{2}{*}{ Treatments } & \multicolumn{4}{|c|}{$\begin{array}{c}\text { Aver. no. of Meloidogyne } \\
\text { javanica juveniles/ } 100 \mathrm{~g} \text { soil }\end{array}$} & \multicolumn{4}{|c|}{ Reduction \% } \\
\hline & $\begin{array}{c}30 \\
\text { Days }\end{array}$ & $\begin{array}{c}60 \\
\text { Days }\end{array}$ & $\begin{array}{c}90 \\
\text { Days }\end{array}$ & $\begin{array}{l}\text { Overall } \\
\text { mean }\end{array}$ & $\begin{array}{c}30 \\
\text { Days }\end{array}$ & $\begin{array}{c}60 \\
\text { Days }\end{array}$ & $\begin{array}{c}90 \\
\text { Days }\end{array}$ & $\begin{array}{c}\text { overall } \\
\text { mean }\end{array}$ \\
\hline A. conoides & $\begin{array}{c}873.8 \\
c\end{array}$ & $\begin{array}{c}592.8 \\
d\end{array}$ & $\begin{array}{c}408.3 \\
c\end{array}$ & $\begin{array}{c}625.0 \\
c\end{array}$ & 20.4 & 51.0 & 74.2 & 51.8 \\
\hline Wormwood & $\begin{array}{c}905.6 \\
b\end{array}$ & $\begin{array}{c}702.8 \\
b\end{array}$ & $\begin{array}{c}520.0 \\
b\end{array}$ & $\begin{array}{c}709.5 \\
b\end{array}$ & 17.5 & 42.0 & 67.1 & 45.3 \\
\hline Tervigo & $\underset{f}{603.2}$ & $\begin{array}{c}380.8 \\
f\end{array}$ & $\begin{array}{c}306.1 \\
\mathrm{e}\end{array}$ & $\begin{array}{c}430.0 \\
f\end{array}$ & 45.1 & 68.5 & 80.6 & 66.8 \\
\hline $\begin{array}{l}\text { A. conoides + } \\
\text { Wormwood }\end{array}$ & $\begin{array}{c}803.5 \\
d\end{array}$ & $\begin{array}{c}610.0 \\
c\end{array}$ & $\begin{array}{c}390.0 \\
\mathrm{~d}\end{array}$ & $\begin{array}{c}601.2 \\
\mathrm{~d}\end{array}$ & 26.9 & 50.0 & 75.3 & 53.6 \\
\hline A. conoides + Tervigo & $\begin{array}{c}619.5 \\
\mathrm{e}\end{array}$ & $\begin{array}{c}340.0 \\
g\end{array}$ & $\begin{array}{c}188.9 \\
f\end{array}$ & $\begin{array}{c}382.8 \\
\mathrm{~g}\end{array}$ & 44.0 & 71.9 & 88.1 & 70.5 \\
\hline Wormwood + Tervigo & $\underset{f}{600.0}$ & $\begin{array}{c}436.7 \\
\mathrm{e}\end{array}$ & $\begin{array}{c}299.7 \\
\mathrm{e}\end{array}$ & $\begin{array}{c}445.5 \\
\mathrm{e}\end{array}$ & 45.4 & 63.9 & 81.0 & 65.6 \\
\hline $\begin{array}{l}\text { A. conoides + } \\
\text { Wormwood + Tervigo } \\
\text { Control }\end{array}$ & $\begin{array}{c}489.6 \\
g \\
1098.2\end{array}$ & $\begin{array}{c}201.8 \\
h \\
1210.0\end{array}$ & $\begin{array}{c}87.9 \\
9 \\
1580.3\end{array}$ & $\begin{array}{c}259.8 \\
h \\
1296.2\end{array}$ & 55.4 & 83.3 & 94.4 & 80.0 \\
\hline (nematode only) & a & a & a & a & - & - & - & - \\
\hline Check & 0 & 0 & 0 & 0 & 0 & 0 & 0 & 0 \\
\hline LSD 5\% & 8.7 & 8.7 & 8.7 & 8.7 & - & - & - & - \\
\hline
\end{tabular}

Means in each column followed by the same letter (s) are not significantly difference at $5 \%$ level.

As for the effect of treatments on some vegetative characters and root gall index of Courgette plants infested with root knot nematode , $M$. javanica, the statistical analysis of the obtained data in Table (6) indicated that there are significant differences in all tested measurements between control and all other treatments.

It was clearly show that all treatments led to considerable increment of plant height, shoot weight and root weight and considerable decrement in root gall index 
(RGI) comparing to control (nematode only). The highest increment was obtained with treatment of $(A$. conoides + Wormwood + Tervigo) while the least increment was observed by Tervigo (half dose).

Table (6): Influence of treatments on some Courgette plant characters and root gall index.

\begin{tabular}{lcccc}
\hline Treatments & $\begin{array}{c}\text { plant } \\
\text { height } \\
\text { cm }\end{array}$ & $\begin{array}{c}\text { shoot } \\
\text { weight } \\
\text { g }\end{array}$ & $\begin{array}{c}\text { root } \\
\text { weight } \\
\text { g }\end{array}$ & $\begin{array}{c}\text { root gall } \\
\text { index }\end{array}$ \\
\hline A. conoides & 28.5 & 16.3 & 10.5 & 3.0 \\
& $\mathrm{bc}$ & $\mathrm{d}$ & $\mathrm{bc}$ & $\mathrm{bc}$ \\
Wormwood & 30.0 & 19.0 & 11.8 & 3.5 \\
& $\mathrm{bc}$ & $\mathrm{cd}$ & $\mathrm{b}$ & $\mathrm{b}$ \\
Tervigo & 27.6 & 18.0 & 10.0 & 2.0 \\
& $\mathrm{c}$ & $\mathrm{cd}$ & $\mathrm{c}$ & $\mathrm{bcd}$ \\
A. conoides + Wormwood & 31.5 & 19.5 & 12.0 & 2.5 \\
& $\mathrm{~b}$ & $\mathrm{~cd}$ & $\mathrm{~b}$ & $\mathrm{bcd}$ \\
A. conoides + Tervigo & 29.0 & 19.0 & 10.8 & 1.5 \\
& $\mathrm{bc}$ & $\mathrm{cd}$ & $\mathrm{bc}$ & $\mathrm{cd}$ \\
Wormwood + Tervigo & 30.4 & 20.0 & 11.5 & 2.5 \\
& $\mathrm{bc}$ & $\mathrm{bc}$ & $\mathrm{bc}$ & $\mathrm{bcd}$ \\
A. conoides + Wormwood & 35.5 & 23.0 & 13.9 & 1.0 \\
Tervigo & $\mathrm{a}$ & $\mathrm{ab}$ & $\mathrm{a}$ & $\mathrm{d}$ \\
& 18.9 & 10.0 & 7.3 & 5.5 \\
Control (nematode only) & $\mathrm{d}$ & $\mathrm{e}$ & $\mathrm{d}$ & $\mathrm{a}$ \\
& 36.8 & 24.0 & 12.0 & 0 \\
Check & $\mathrm{a}$ & $\mathrm{a}$ & $\mathrm{b}$ & 0 \\
LSD 5\% & 3.4 & 3.4 & 1.7 & 1.7 \\
\hline
\end{tabular}

Table (7): Increase or decrease percentages of some vegetative characters and gall index on Courgette as influenced by treatment applications.

\begin{tabular}{lcccc}
\hline \multicolumn{1}{c}{ Treatments } & $\begin{array}{c}\text { plant } \\
\text { height } \\
\%\end{array}$ & $\begin{array}{c}\text { shoot } \\
\text { weight } \\
\%\end{array}$ & $\begin{array}{c}\text { root } \\
\text { weight } \\
\%\end{array}$ & $\begin{array}{c}\text { root gall } \\
\text { index } \\
\%\end{array}$ \\
\hline A. conoides & 50.7 & 63.0 & 43.8 & -45.5 \\
Wormwood & 58.7 & 90.0 & 61.6 & -36.4 \\
Tervigo & 46.0 & 80.0 & 36.9 & -63.6 \\
A. conoides + Wormwood & 66.7 & 95.0 & 64.4 & -54.6 \\
A. conoides + Tervigo & 53.4 & 90.0 & 47.9 & -72.7 \\
Wormwood + Tervigo & 60.8 & 100.0 & 57.5 & -54.5 \\
A. conoides + Wormwood + Tervigo & 87.3 & 130.0 & 90.4 & -81.8 \\
Control (nematode only) & - & - & - & - \\
Check & 94.7 & 140.0 & 64.4 & - \\
\hline
\end{tabular}


As for the increase or decrease percentages of the tested characters Table (7), the obtained results indicated that all plant treatments increased plant height, shoot weight, root weight, while it decreased root gall index.

The obtained results from the addition of Tervigo + wormwood $+A$. conoides proved that Tervigo pesticide had no adversely effect on $A$. conoides.

\section{References}

Abbott, W.S. (1925). A method of computing the effectiveness of an insecticide. J. Econ. Entomol.; 18 : 265-267.

Akhtar, M. and M. M. Alam (1991). Integrated control of plant parasitic nematodes on potato with organic amendments, nematicide and mix cropping with mustard. Nematologia Mediterranea, 19:2, 169-171.

Barker, K.R.,(1985). The application of microplot techniques in nematological research. In: Baker, K.R., Carter, C.C., Sasser, J.N. (Eds.), . In: An Advanced Treatise on Meloidogyne. Methodology, Raleigh, Vol. II. North Carolina State University Graphics, pp. 127-134.

Cooke R.C. and B.E. Godfrey (1964). A key of nematode-destroying fungi. Transactions of the British mycological society. 47: 61-74.

Keren-Zur M., Antonov J., Berconvitz A. Feldman K., Husid A., Keran G., Marcov N., and Rebhun M. (2000). Bacillus furmus formulations for the safe control of root-knot nematode. In: The BCPC Conf., Pests \& Disease, Brighton, UK. p. 47-52.

Moosavi, M.R., and R. Zare (2012). Fungi as biological control agents of plantparasitic nematodes. In Plant Defense: Biological Control, Progress in Biological Control, Vol. 12, Part 2. Mérillon, J.M., and Ramawat, K.G. (eds). New York, USA: Springer, pp. 67-107.

Mostafa F. A. (2001). Integrated control of root-knot nematodes, Meloidogyne spp. infected sunflower and yomato. Pakistan journal of biological science, 4 (1): 44-46.

Seyedeh, L. N., M.G. Ebrahim, Naser, S., Javaran M. J., Pourjam E., Bakhsh M. S. and Afshar F. J. (2015). The effects of Arthrobotrys oligospora and Arthrobotrys conoides culture filtrates on second stage juvenile mortality and egg hatching of Meloidogyne incognita and Meloidogyne javanica. J. Crop Prot. 4 (Supplementary): 667-674.

Southey J. F. (1970). Laboratory Methods for Work with Plant and Soil Nematodes. Ministry of Agriculture, Fishers and Food. Technical Bulletin 2: 5 th ed., 148 pp.

Van Oorschot CAN (1985). Taxonomy of the Dactylaria complex. V. A review of Arthrobotrys and allied genera. Studies in Mycology. 26: 61-96.

Viaene, N., Coyne, L.D. and Kerry, B.R. (2006). Biological and cultural management, p. 346-369.In: Perry, R. N. and Moens, M. (Eds.). Plant Nematology. CAB International, Wallingford, UK. 


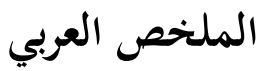

المكافحة المتكاملة لنيماتودا تعقد الجذور التي تصيب نباتات الخيار والكوسة

$$
\text { محمد سعيد أبو قورة }
$$

قسم الحشرات الاقتصادية والحيوان الزراعي - كلية الزراعة - جامعة المنوفية - مصر.

Arthrobotrys تم إجراء هذا البحث لدراسة تأثير كل من الفطر الصائد للنيماتودا Artemisia herba ومسحوق أوراق وسيقان النبات العشبي (الشيح الأبيض) conoides alba للنيماتودا المتطفلة على نباتي الخيار والكوسة.

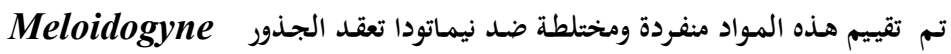
الإب javanica

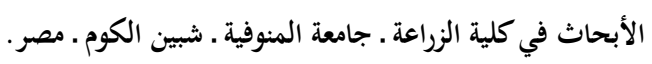

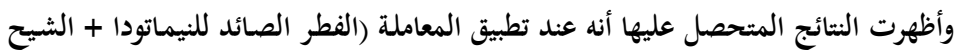

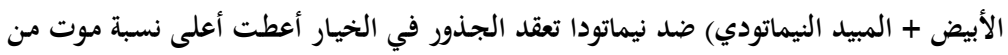

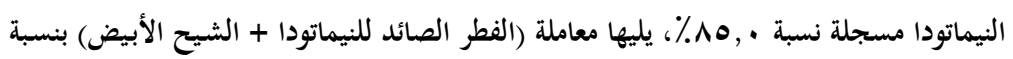

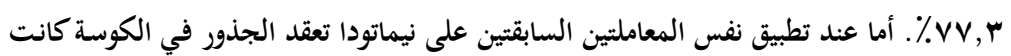

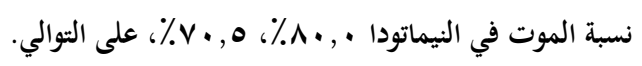

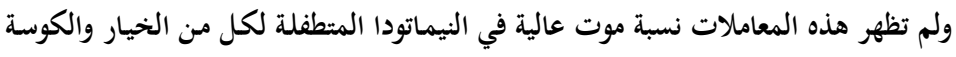

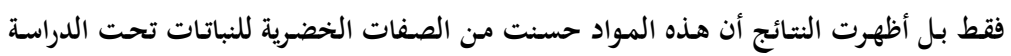

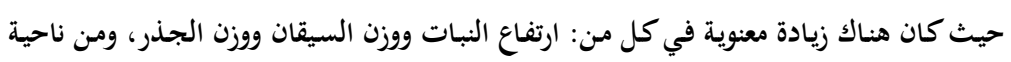

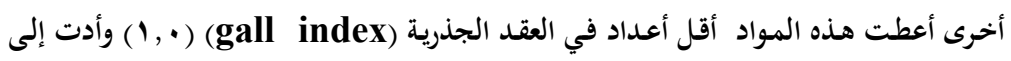

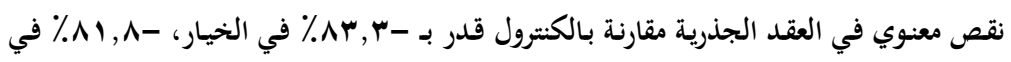

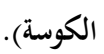

كما أظهرت النتائج وجود فروق معنوية في أعداد العقد الجذرية بين معاملة الكنترول وباقي

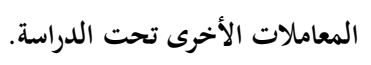

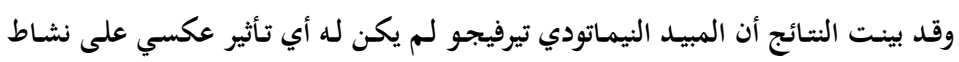

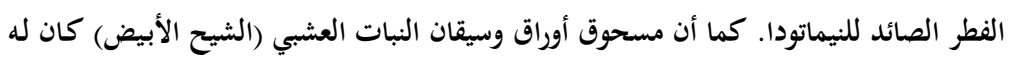
دورًا هامًا في مقاومة النيماتودا وشجع على نمو النما النبات.

ويوصى البحث باستخدام المواد المختبرة في برامج المكافحة المتكاملة لبكات للنيماتودا المتطفلة

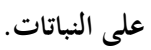

